\title{
Investing in local food, investing in local communities
}

\author{
Review by Thomas Bolles* \\ Virginia Cooperative Extension
}

Review of SO IL : N otes Towards the Theory and Practice

of $\mathrm{N}$ urture Capital, by Woody Tasch. (2017).

Published by Slow Money Institute. Available as

paperback; 166 pages. Publisher's website:

https:// slowmoney.org/ publications/ soil-notes-

towards-the-theory-and-practice-of-nurture-capital

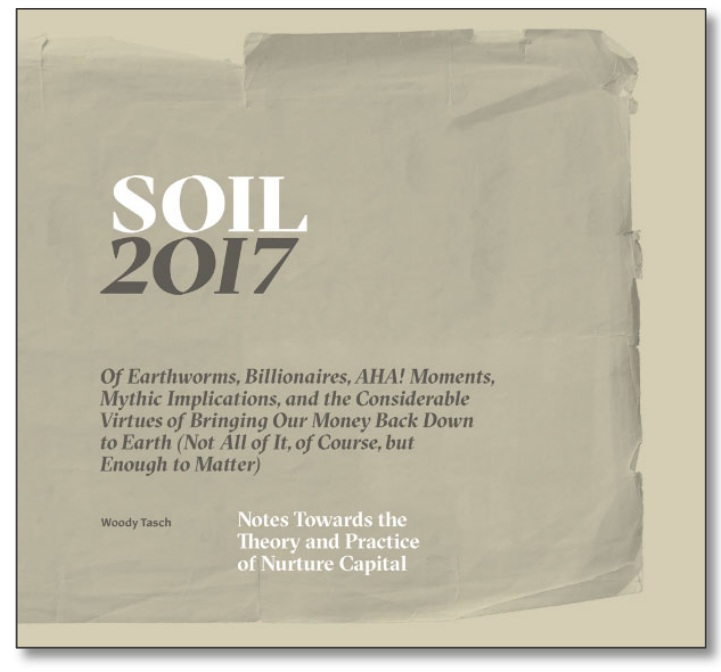

Submitted August 20, 2018 / Published online March 12, 2019

Citation: Bolles, T. (2019). Investing in local food, investing in local communities [Book

review]. Journal of A griculture, Food Systems, and C ommunity D evelopment, 8(4), 223-225.

https:/ / doi.org/ 10.5304/ jafscd.2019.084.017

Copyright @ 2019 by the Author. Published by the Lyson Center for Civic Agriculture and Food Systems. Open access under CC-BY license.

S OIL : N otes Toward the Theory and Practice of

$S_{\mathrm{N}}$ urture is by Woody Tasch, the founder of the Slow Money Institute, which seeks to rebuild the economy from the ground up with an emphasis on sustainable local food systems. This book lays out Tasch's vision for building local food systems.

SO IL is an interesting and entertaining read. It is not a just-can't-put-it-down read, but I think that is the point. Festooned with side notes, the text forces you to break up the read. In many cases, the notes not only tie into the text but also are teaser for the reader to go back and dig deeper. Tasch's writing style is hard to define, but it has a very

* Thomas Bolles is an educator with Virginia Cooperative Extension. His work includes supporting school and community gardens, promoting soil health, and nutrient management. His interests include food safety and security, development, and alternative crops. He can be contacted at tpbolles@ vt.edu. literary quality. The text is more a conversation than a formal dissertation. Tasch engages the reader, circling back and tying up his points to weave a plan of hope for the future.

The book is divided into two parts. Part O ne, Poetically Inoorrect, is filled with stanzas and stories to get the reader comfortable with the sometimesnonlinear journey they have embarked upon. It makes it clear this is not your typical book about soil or economics.

Part Two, Imagination, is divided into four chapters. In begins with $\mathrm{W}$ hereabouts, which offers an introduction to what is to come and makes a case for imaginative thinking and balance as we look to the future.

In Return, Tasch lays out the importance of giving back - back to the land and back to the community. This chapter is not a call for a socialist 
utopia. It lays out a model for sustainability that fits within a capitalist framework. It starts with the importance of returning carbon to the earth, a task humanity has largely ignored as civilization has advanced. The book offers an eclectic band as part of the solution to our carbon problem- a colonial administrator turned composter, an actor turned philanthropist, and hordes of soil dwellers.

Sir Albert Howard's observations in India led him to understand the stability of the natural cycle of growth and decay. He became the father of farming in concert with nature. He saw the value of working with nature, not against it.

Paul Newman believed we should be like the farmer who puts back into the soil what he or she takes out. He put this into practice by creating a company that donates $100 \%$ of its profits to charities. Though Newman's $\mathrm{O}$ wn is discussed early in the chapter, the book later circles back to how philanthropy has begun to evolve from the make-as-much-money-as-possible-and-give-someof-it-away model to a model that involves investing locally and slowly in enterprises that are critical to the health of the community, the homes within it, and the soil beneath it.

The importance of soil health has become more evident in recent years. The book discusses the special relationships microbial populations in the soil have with plants. It also references the microbial universe in the gut which were brought to light in The $\mathrm{H}$ idden $\mathrm{H}$ alf of $\mathrm{N}$ ature by Montgomery and Bliké. The book shows how fair trade can be a reflection of these natural, symbiotic systems.

Also, within this chapter is a discussion of the modern economy. As life has sped up, the growth of economies has been exponential. The drive for ever increasing returns has moved us to a point where we have made decisions for monetary return without considering the effects. The argument is made that this type of investing tends to pull money and vitality out of communities, as money is concentrated in national and international corporations instead of being retained locally to be reinvested in the communities' health and welfare.

O ne of the interesting points raised is what gross domestic product measures and, more importantly, what it does not. GD P can show economic growth, but that doesn't always translate to progress and happiness. GDP relates to the quantity of cash flow, not why it flows. GDP considers money spent cleaning up a toxic spill to be the same as money flowing into school lunch programs. Relying solely on GDP does not give a clear picture of how cash flow affects quality of life and the health of communities.

The third chapter in Part Two, N urture, focuses on the importance of nurture capitalism. A subset of capital expenditure at the intersection of investment and philanthropy, nurture capitalism is the idea that investing in local food systems nurtures the land, the community, and the businesses that support them. This type of investing allows more money to stay in the community and helps the community remain viable.

Nurture capitalism is an investment in more than just businesses. It is an investment in the health and well-being of the land and people that make up a community. It allows for food systems based on sustainable ecological principles to be financially stable. Nurture capitalism is an investment in a quality of life, where the intrinsic returns are shared by the community.

The book does not argue for an economy based solely on local investment. It asserts that as so much of the economy is rooted in the national and global interest of bigger and faster returns that meaningful local investment has been lost. By investing locally, we can achieve more balance in the capitalist system.

The final chapter, $\mathrm{H}$ ereabouts, discusses how supporting local food systems is complementary to commodity agriculture and global distribution systems. It argues that local food systems allow for more diversity in what is grown as well as more organic farms. This allows for healthier food choices, a healthier environment, and healthier communities.

Included in this chapter are pragmatic steps for putting money back into communities. Individually, things such patronizing farmers markets, community supported agriculture farms (CSAs), local food retailers, and farm-to-table restaurants help to keep money in the community. Collectively, through nongovernmental organizations (NGOs) and political action, engagement in the community can bring about positive change. 
This chapter also includes the case study of Slow O pportunities for Investing Locally (SO IL), a nurture capital group in Colorado. The capital comes from locally generated donations. Anyone who donates receives one vote in decisions made by the group, regardless of how much they donate. SO IL then offers interest-free loans to support local food systems.
SOIL lays out the principles of slow money in an entertaining and engaging way. It concludes with a call to determine what we value and take action for the betterment of the community. It challenges us to contribute to an economy that is based on restoration and health, rather than consumption and wealth. 